\title{
Mt Kembla Mine rehabilitation and memorial pathway: a case study of effective stakeholder engagement to ensure successful final land use planning and environmentally and socially sensitive project outcomes
}

\author{
A.J. Larance Cardno (NSW/ACT) Pty Ltd, Australia
}

\begin{abstract}
This project represents an innovative approach to mine rehabilitation and beneficial final land use of a degraded mine site where social, environmental and economic values are strengthened in the outcomes.

BHP Billiton Illawarra Coal provided the commitment and Cardno Pty Ltd the supporting concept design, planning, and engineering expertise to ensure effective mine rehabilitation techniques to culminate in a stable, non-polluting and long term sustainable site that will allow future mining lease relinquishment.

A multi-stage project known as the 'Mt Kembla Mine Memorial Pathway' has been planned and developed along a section of the original train haulage route from the historic Mt Kembla and Nebo Colliery sites to the Port Kembla steelworks. A major aim for the site was to sympathetically commemorate Australia's most significant mine disaster. In 1902 a total of 96 miners lost their lives when a gas explosion occurred within a mine portal situated above the small coal mining village of Mt Kembla in the foothills of the Illawarra Escarpment, just west of Wollongong in New South Wales, Australia (NSW). The project planning and design team were committed to providing a community focused recreational pathway, heritage interpretation area and small scale residential subdivision that was sympathetic to the natural and built environment.
\end{abstract}

Stage 1 of the project was completed in 2008 and Stage 2 of the project commenced planning in 2010 with all development approvals being issued in February 2012.

The project planning constraints were complex and an array of future land uses were proposed including private, public recreation and environmentally sensitive spaces. A range of specialists undertook site investigations and design activities to identify constraints and opportunities. A well resolved landscape design was developed that satisfied all local Council planning approvals and mining lease requirements.

Community engagement played an integral role in the planning and development. An inclusive approach was undertaken whereby community needs, ideas and concerns were incorporated directly into the concept site layout designs and a final preferred landform design. Community members are now able to tangibly recognise their input into the design in Stage 1 and will see many of their ideas eventuate as Stage 2 construction is completed.

Improved environmental values have also been integral to the rehabilitation of the ex-mining land. The rehabilitation works improve the ecological health of the natural environment and creek system, and improve the habitat for flora and fauna. This has been achieved through stabilisation and erosion control of steep rail cuttings and creek banks and restoration of the ecological connectivity of fragmented riparian zones through native vegetation establishment.

Whilst the formal ownership of Stage 1 of the pathway was dedicated to local Council as public open space, much of the maintenance of site vegetation and infrastructure is undertaken by Illawarra Coal and local residents who have taken pride and 'ownership' of the area due to their involvement in the design and construction process. To date there has been limited financial obligations on the site owner for site enhancements and ongoing maintenance as the community has actively sought voluntary assistance, grants and donations to finance these parts of the project. It is likely that similar on-ground community involvement will also occur in Stage 2. 
This project serves as a working and innovative example of how an ex-mine site can achieve beneficial outcomes for multiple parties whilst responsibly maintaining and fostering important community values.

\section{Introduction}

This case study outlines how a committed approach to stakeholder engagement and involvement in developing final land use and site design provides successful community outcomes for a mine site rehabilitation and urban design project.

This paper aims to outline the approaches utilised and lessons learned during the process of obtaining project approval prior to commencement of the extensive rehabilitation and final land use redevelopment works.

\section{Background}

BHP Billiton Illawarra Coal currently owns land between Kirkwood Lane and Stones Road in Mt Kembla ('the site'). The site was previously part of the former Mt Kembla and Nebo Collieries rail link to Port Kembla and is still under a Mining Lease (CCL 768). The Dendrobium Mining Operations Plan (MOP) covers the ongoing management and rehabilitation requirements of the site.

The site is closely linked to the operation of two significant collieries - Mt Kembla which dates from 1880 and Nebo, which operated from 1946-1993. A mine disaster occurred near the site in 1902, when a total of 96 miners lost their lives within the Mt Kembla Mine portal gas explosion (Rogers, 2005). The development of the Mt Kembla Mine Memorial Pathway is a commemorative initiative to recognise this event.

The original landform of the valley floor and lower slopes of the site have been extensively modified by earthworks associated with the construction (and subsequent demolition) of coal transport facilities for these mines. The western end, adjacent to Kirkwood Lane, was excavated to provide space for the Nebo Colliery sidings (Rogers, 2005), which are clearly shown in Figures 1 and 2.

As the site was previously utilised for mining operational purposes, it has a requirement under the Mining Act 1992 to be rehabilitated to a standard which provides a stable, non-polluting and long term sustainable site, and which allows suitable final land use. The degraded state of the site required extensive rehabilitation and an opportunity existed to provide amenity improvements to the local community as part of the project. Illawarra Coal developed a consultation strategy and engaged with the community in the early stages of project development to better understand their wishes, expectations and ideas for improvements at the site up front.

Illawarra Coal originally made a community commitment to provide land to establish the Mt Kembla Mine Memorial Pathway. The local community were closely engaged to identify other enhancement opportunities which could arise from the required rehabilitation works that needed to be completed in parallel with the pathway development. Illawarra Coal donated a significant portion of the land to local Council for community amenity and funded the design, planning approvals and construction of the rehabilitation work elements of the project. A portion of the Stage 2 pathway infrastructure will be funded through the Dendrobium Community Enhancement Program (DCEP), set up by the Company to fund local community projects.

Construction and rehabilitation works commenced in early 2012 and the final site design incorporates ecological restoration, recreational amenity and residential subdivision development features. 


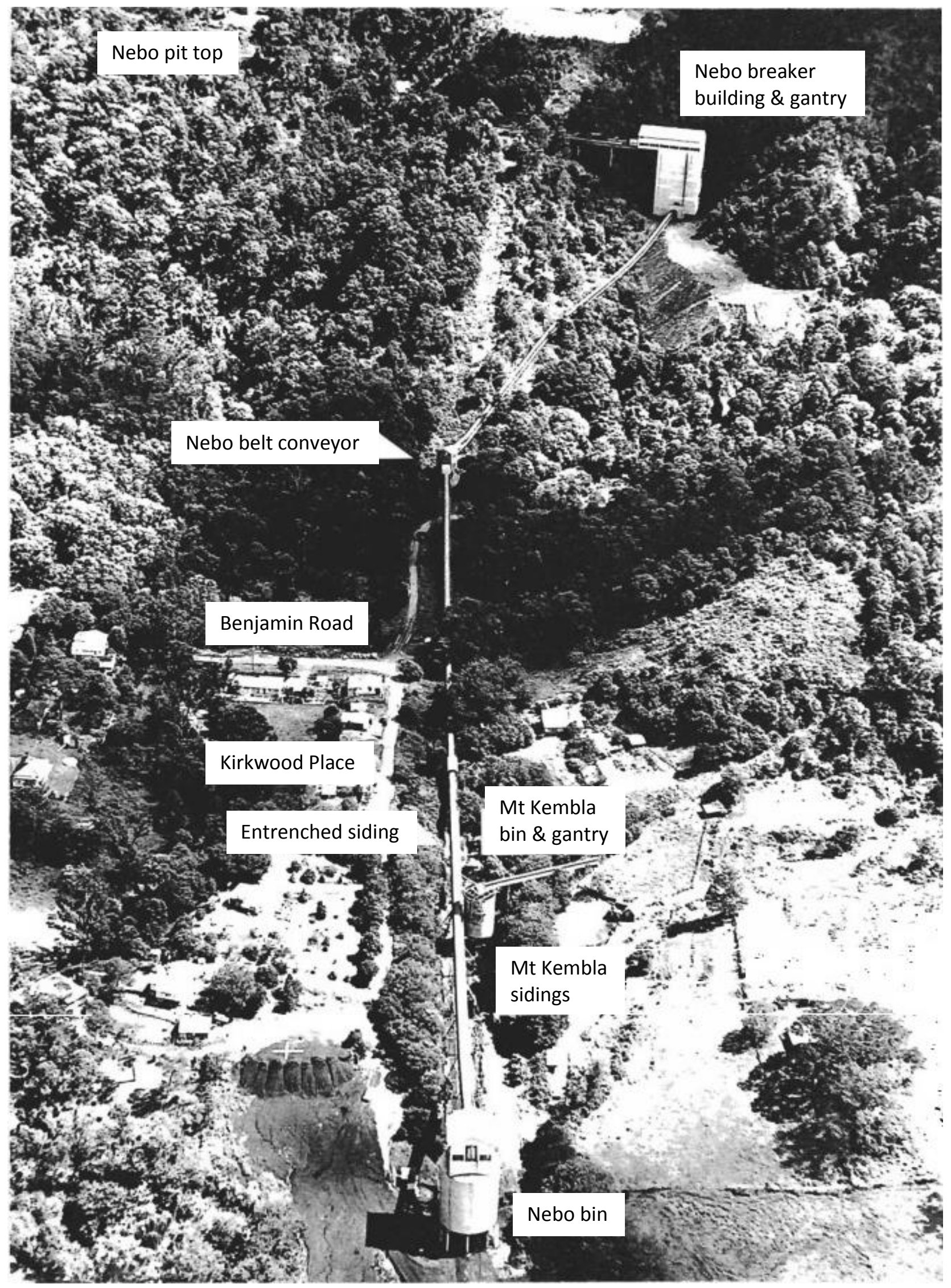

Figure 1 Photograph showing Nebo coal bin, conveyor and Bradford breaker building, viewed west in 1978. Note the close proximity of existing houses to the mining infrastructure along Kirkwood Place, source: Rogers (2005) 


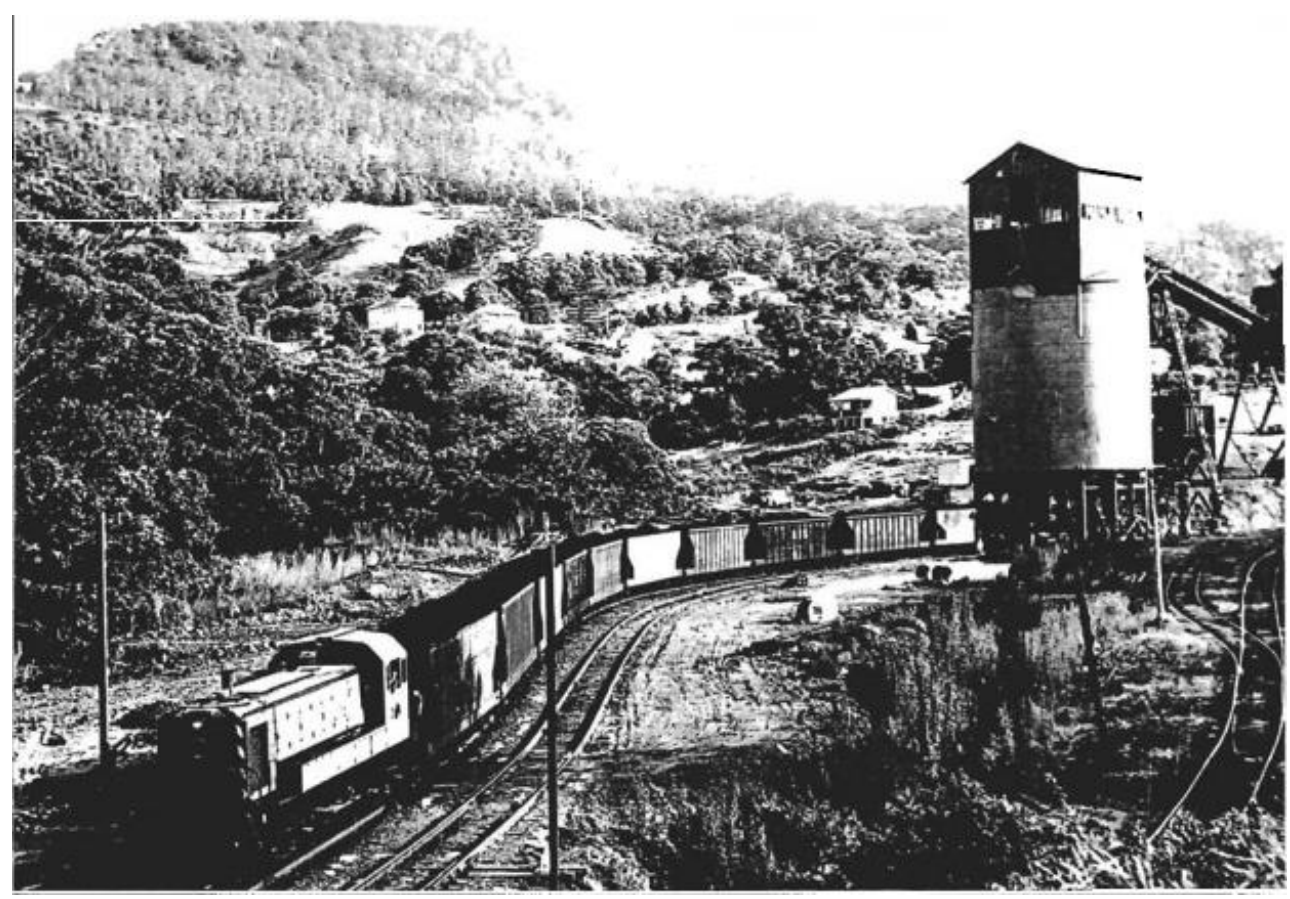

Figure 2 Diesel electric locomotive and train of $60 t$ wagons transport coal from the 2,000 $t$ Nebo bin (photo taken mid 1950s), source: Rogers (2005)

\subsection{Objectives of the project}

The main objectives of the rehabilitation project were:

- To consider the views and ideas of the community in the development of a site master plan.

- To rehabilitate the site to achieve a safe, stable and non-polluting landform that will accommodate appropriate final land uses.

- To rehabilitate the site to provide improved aquatic/terrestrial ecological outcomes and to solve erosion issues on steep and unstable creek and railway embankments.

- To provide improved public walkway access and recreational opportunities through Mt Kembla Village by extending the existing Mt Kembla Mine Memorial Pathway.

- To beneficially reuse the mine waste product coal wash as a fill material where possible.

- To provide dedicated spaces for cultural heritage interpretive features.

- To provide a small scale residential subdivision on an appropriately zoned portion of the site.

- To apportion and transfer ownership of the site to both private and public entities that will include Wollongong City Council.

A critical component of the project was to combine the mine rehabilitation works with quality urban design features to deliver a high quality public space that will achieve functional, aesthetic, safety and sustainable land use goals.

\subsection{Project planning and development team}

Stage 1 of the Mt Kembla Mine Memorial Pathway was completed in 2008.

The environmental planning, landscape architect and engineering team were responsible for the planning and design of Stage 2 in 2010-2011. Input and support was provided to the team from the Mt Kembla Pathway Group and local community. Stage 2 is currently under the final phases of bulk earthworks and facilities construction. It is expected that the preliminary revegetation work will be completed by late 2012 . 


\section{Site master plan concept development}

The development of a site master plan was an initial focus of the project team. The team, with assistance from Illawarra Coal, invited the community to provide comments to feed ideas into the initial design concepts. A number of environmental studies, including extensive ecology and heritage assessments, were completed previously as part of a land rezoning application involving the site back in 2005. These reports were also reviewed to identify any potential constraints and opportunities. Additional site survey, hydrological, arborist, bushfire, site contamination and geotechnical assessments were then completed to help identify any other site issues or constraints requiring consideration. These studies enabled a thorough site analysis which then informed the final design of the master plan concept.

\subsection{Site analysis}

The site is characterised by naturally undulating to steep topography. A narrow elevated plateau is located at the eastern end of Kirkwood Lane and slopes gently down towards American Creek on its eastern and southern sides. This area was identified as the most suitable location for any residential development due to its elevation above the lower flood prone areas of the site. A lower central corridor runs west to east from the toe of a steep embankment below Kirkwood Lane, which contains a drainage gully along the northern boundary of the site (Cardno Pty Ltd, 2011).

The site has been subject to extensive land form modification during the historic construction of the former mine rail infrastructure, which has created steep cuttings and embankments. Many of these steep embankment features were identified as being inherently unstable and are required to be reshaped and stabilised during the rehabilitation works (Douglas Partners, 2011). The findings of the geotechnical assessment fed into the bulk earthworks scope and final engineered landform design.

The future site land uses have been planned to comply with zoning restrictions outlined in the Wollongong Local Environment Plan 2009, which are meant to designate appropriate and suitable future land uses.

The southern central portion of the site is zoned 'E4 Environmental Living', which permits (with consent): community facilities; dwelling houses; earthworks; environmental facilities; environmental protection works; recreation areas; roads; and secondary dwellings (Wollongong City Council, 2009).

The eastern portion of the site is zoned 'RE1 Public Recreation', which permits (with consent): community facilities; environmental facilities; environmental protection works; extensive agriculture; information and education facilities; markets; recreation areas; recreation facilities (outdoor); roads; and signage (Wollongong City Council, 2009).

The remaining western areas of the site are zoned 'E3 Environmental Management', which permits (with consent): community facilities; dwelling houses; earthworks; environmental facilities; environmental protection works; extensive agriculture; farm buildings; farm stay accommodation; recreation areas; roads; and secondary dwellings (Wollongong City Council, 2009).

A site location, boundary and zoning plan is shown as Figure 3.

\subsection{Key site elements and constraints}

The entire site is also designated as 'Bushfire Prone' within local planning maps (Wollongong City Council, 2009), which required the design to comply with the Planning for Bushfire Protection 2006 guideline.

Regulations within the Water Management Act 2000 state that all controlled activities within $40 \mathrm{~m}$ of waterfront land, require Controlled Activity Approval from the NSW Office of Water. Therefore the vegetation management and earthwork activities under the American Creek waterfront land required Controlled Activity Approval prior to works commencing.

The main site constraints that needed to be considered in the planning and design phase included:

- local environmental plan zoning 
- other planning instruments, regulations and controls

- steep topography and unstable embankments

- significant water course and flooding risks

- bushfire risk

- significant weed infestation.
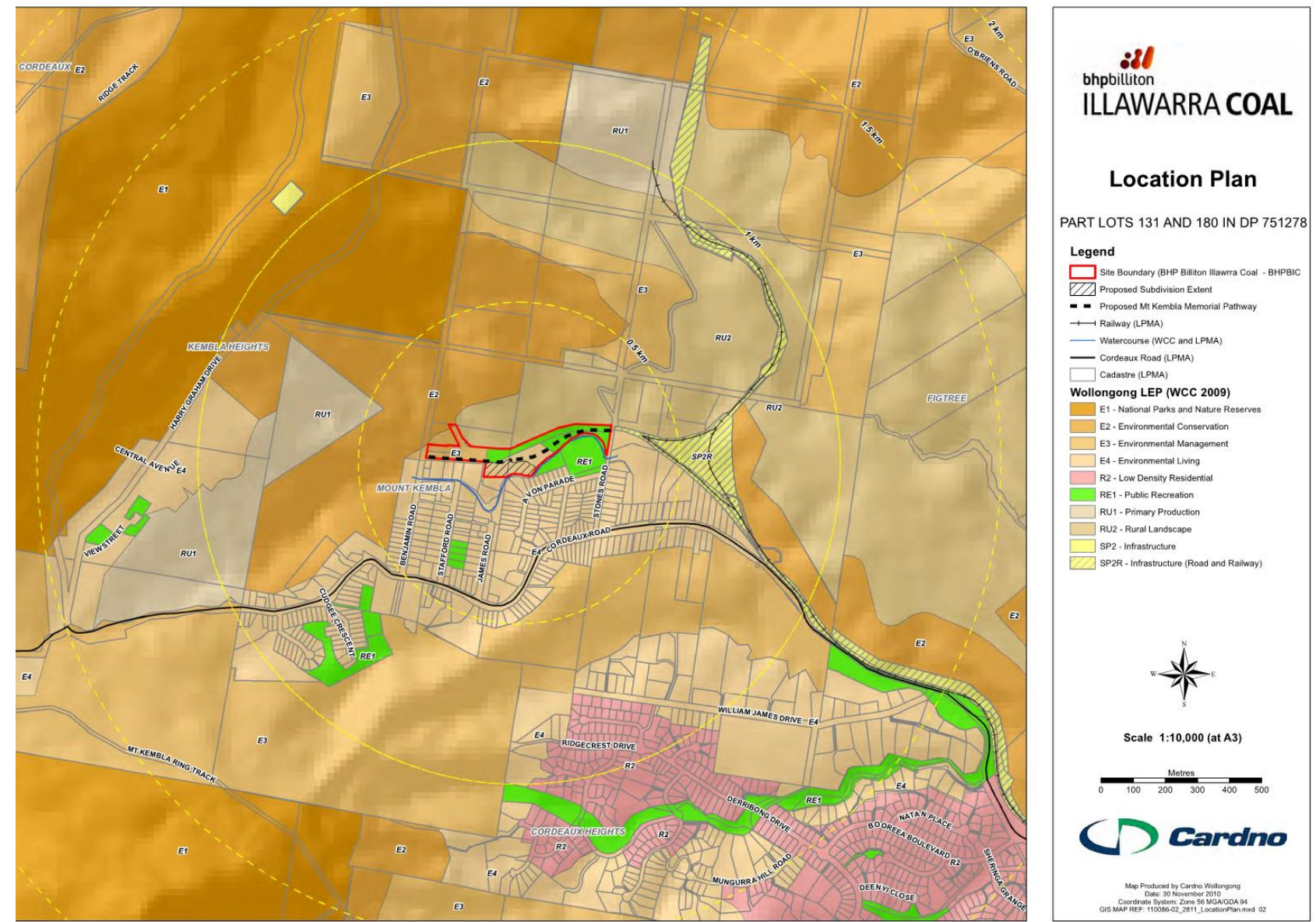

Figure 3 Location plan of the site showing adjacent Wollongong Local Environment Plan zoning boundaries, source: Cardno Pty Ltd (2011)

\subsection{Site context and surrounding land uses}

The locality surrounding the site has a semi-rural residential character. The locality has a strong historical link with the mining industry and this is the predominant character of the area. The majority of the dwellings in the locality are characterised as single storey detached cottages (Cardno Pty Ltd, 2011).

The surrounding land use is mainly characterised by a mix of low density and semi-rural residential properties. The Mt Kembla Village centre is located just to the south of the site (see Figure 4) and ongoing coal mining activities also occur nearby. The site is also bounded to the south by American Creek, which is a significant water course running through the area. The existing developments are mainly single storey residential detached dwellings. Adjoining undeveloped land to the west is currently owned by Illawarra Coal and the properties to the north are long held private rural holdings (Cardno Pty Ltd, 2011). 


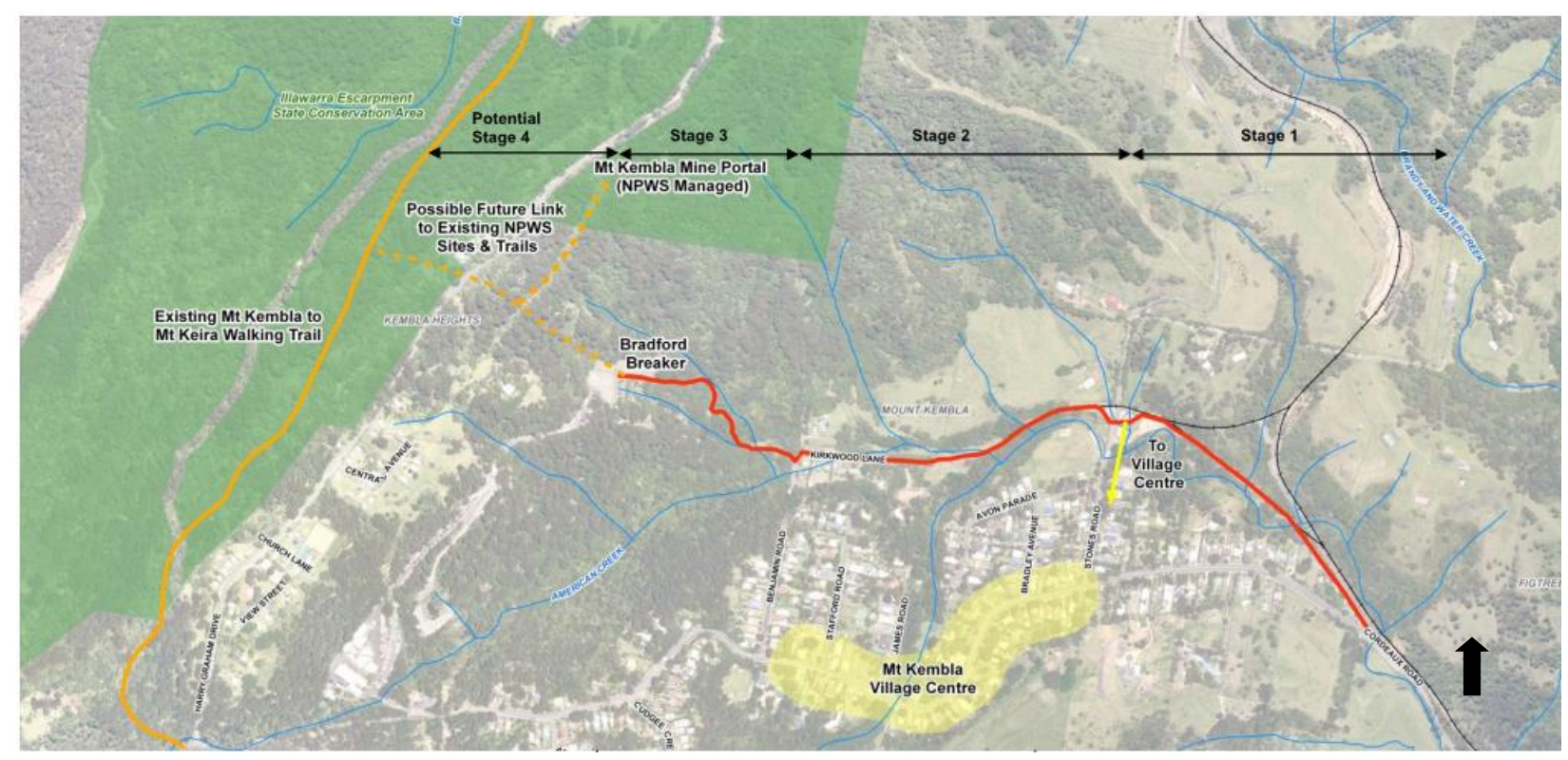

Figure 4 Map showing extent of Mt Kembla Mine Memorial Pathway stages (current and proposed) and locality context, source: Cardno Pty Ltd (2011)

\subsection{Community stakeholder engagement}

The strong relationships that Illawarra Coal have developed and forged with the local Mt Kembla community have been integral to the success of this project to date. The open communication lines developed through the representative committee named the 'Mt Kembla Mine Memorial Pathway Group' and regular community consultation meetings have provided for effective two-way communications between the company and the community. It was within these regular forums as well as follow up meetings on site (see Figure 5) that ideas were pitched, concept designs were tabled and the varieties of options were discussed and feedback was sought. Written proposals and proposed site concepts developed by a variety of community members were also provided during these forums.

The community were involved from early project scoping stages and then extensively throughout the development of the overall site master plan. This included determining landscape features across the site and selection of sympathetic materials for construction and species for the proposed revegetation works. The proposed location, size and details of the proposed residential allotments were also openly discussed with the community.

Trust is an important factor when engaging a community partner in a collaborative project. Trust can be eroded if the community engagement methods used are inappropriate, or promise a level of involvement or decision making that is not delivered (Department of Sustainability and Environment, 2004).

A commitment was made by Illawarra Coal to foster trustworthy, open and extensive community engagement to ensure that any opportunities, values and concerns could be identified and considered throughout the planning and design processes. Active engagement with community stakeholders (in particular local communities and land owners), results in less resistance from key stakeholders, lower financial burdens in the mine closure and rehabilitation phases, and lower risk of significant liabilities postclosure (Environment Australia, 2002).

The thorough community engagement process ensured that potential issues and ideas could be identified and/or factored into the designs prior to submission of the Development Application (DA). This played a significant role in ensuring risks of negative public submissions during the exhibition period were minimised which could have negatively affected the overall scope, schedule and budget of the rehabilitation project. The success of the consultation process was evidenced by the receipt of only two formal written submissions from the community during the DA assessment process. The theme of these submissions was 
mainly related to the extent of the proposed residential subdivision, which had been previously scaled back in size and numbers of allotments in response to concerns raised early in the consultation process. On review of the small volume of submission received by Council, the final subdivision size was deemed to be acceptable and the project was approved.

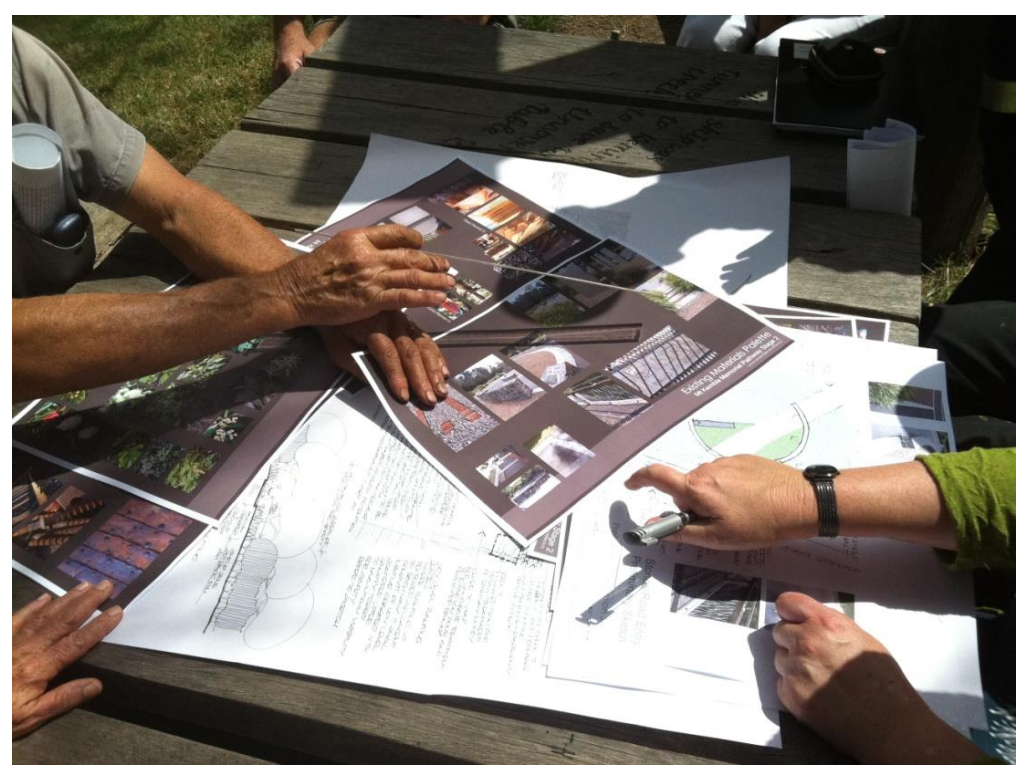

Figure 5 Onsite review of proposed design concepts involving Mt Kembla Mine Memorial Pathway Committee members and the project planning and design team

The range of factors identified through the community consultation process for consideration in the creation of the site concept master plan, are included in Table 1.

\section{Table 1 Factors for consideration during development of the site concept master plan}

\begin{tabular}{|c|c|c|}
\hline Opportunities & Values & Concerns \\
\hline $\begin{array}{l}\text { Improve connectivity within the } \\
\text { Mt Kembla Village }\end{array}$ & $\begin{array}{l}\text { Cultural heritage } \\
\text { (appreciation of local } \\
\text { mining history) }\end{array}$ & $\begin{array}{l}\text { Ensuring that appropriate endemic } \\
\text { species are used within the re-vegetation } \\
\text { works }\end{array}$ \\
\hline $\begin{array}{l}\text { Recreational area (incl. exercise } \\
\text { areas, foot and cycle path) }\end{array}$ & Biodiversity & $\begin{array}{l}\text { Size and character of new buildings } \\
\text { within the new residential subdivision }\end{array}$ \\
\hline $\begin{array}{l}\text { Heritage display and interpretation } \\
\text { areas }\end{array}$ & Community spirit & $\begin{array}{l}\text { Unsympathetic development i.e. } \\
\text { character of buildings, fence materials } \\
\text { and overly formal roadway design }\end{array}$ \\
\hline Educational and tourist attraction & $\begin{array}{l}\text { Aesthetics to be } \\
\text { sympathetic to natural and } \\
\text { built village environment }\end{array}$ & $\begin{array}{l}\text { Hard engineering works and other } \\
\text { unnatural features will be used to } \\
\text { stabilise banks within American creek, i.e. } \\
\text { sprayed concrete, block retaining walls }\end{array}$ \\
\hline $\begin{array}{l}\text { Erosion control and bank } \\
\text { stabilisation }\end{array}$ & $\begin{array}{l}\text { Recreational amenity to } \\
\text { promote health and } \\
\text { wellbeing of local residents } \\
\text { and visitors }\end{array}$ & \\
\hline \multicolumn{3}{|l|}{$\begin{array}{l}\text { Access improvements to private } \\
\text { properties adjacent to site }\end{array}$} \\
\hline $\begin{array}{l}\text { Residential development within } \\
\text { appropriately zoned site areas }\end{array}$ & & \\
\hline
\end{tabular}




\subsection{Concept master plan design elements}

The concept master plan for the site rehabilitation and development has incorporated items and areas for a number of community focused features. This included a continuation of the existing Stage $1 \mathrm{Mt}$ Kembla Mine Memorial Pathway from the Stones Road car park west through the site and up along Kirkwood Lane, where it terminates at Benjamin Road. A number of similar features to those provided by community members and groups in Stage 1 (see Figure 6) and remnant infrastructure with heritage value which can be preserved similar to the rail line shown in Figure 7 will be expected in Stage 2.

A heritage display area was situated on an elevated vantage point in the central portion of the site which allows views both west and east along the site, enabling interpretive displays to highlight the previous historic uses within the site and on adjacent lands. The location of the heritage display area also allows a wide vista of the Illawarra escarpment to the north and west, which will provide valuable interpretive and educational reference potential (Cardno Pty Ltd, 2011).

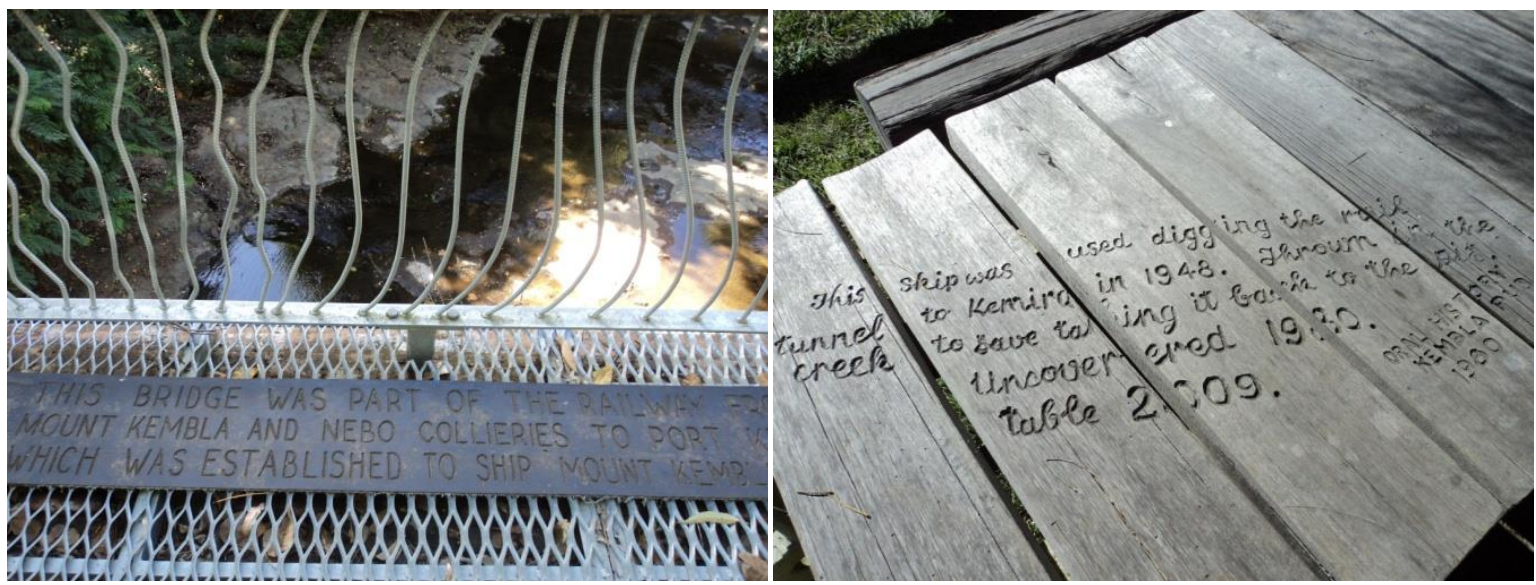

Figure 6 Examples of features included in Stage 1, which include an ornate bridge over American Creek with engraved conveyor belt feature (left) and inscribed picnic table top (right), source: Cardno Pty Ltd (2011)

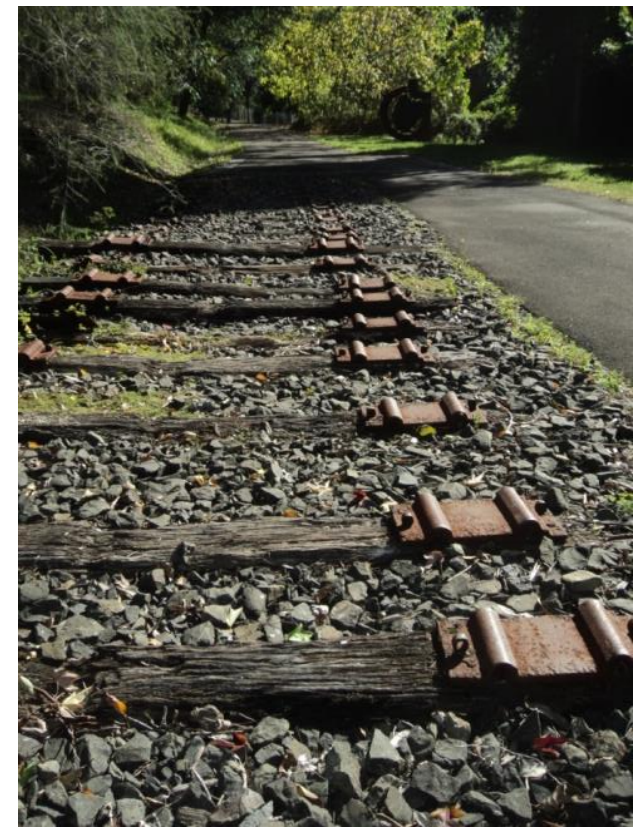

Figure 7 Remnant timber sleepers and ballast from old railway line. This is a key interpretive element from Stage 1 of the Mt Kemble Mine Memorial Pathway which physically demonstrates the alignment of the original rail line, source: Cardno Pty Ltd (2011) 
The steep rail cuttings and unstable creek banks will be stabilised using fill and shallow batters with revegetated surface treatments where possible (Douglas Partners, 2011). Some areas of the creek will require the installation of rock armouring to prevent bank erosion. A steep site embankment requires a gabion wall earth retaining structure to provide a stable pathway thoroughfare and to satisfy high flow flood management requirements (Cardno Pty Ltd, 2011). Photographs showing the construction status as of July 2012 are shown in Figure 8.
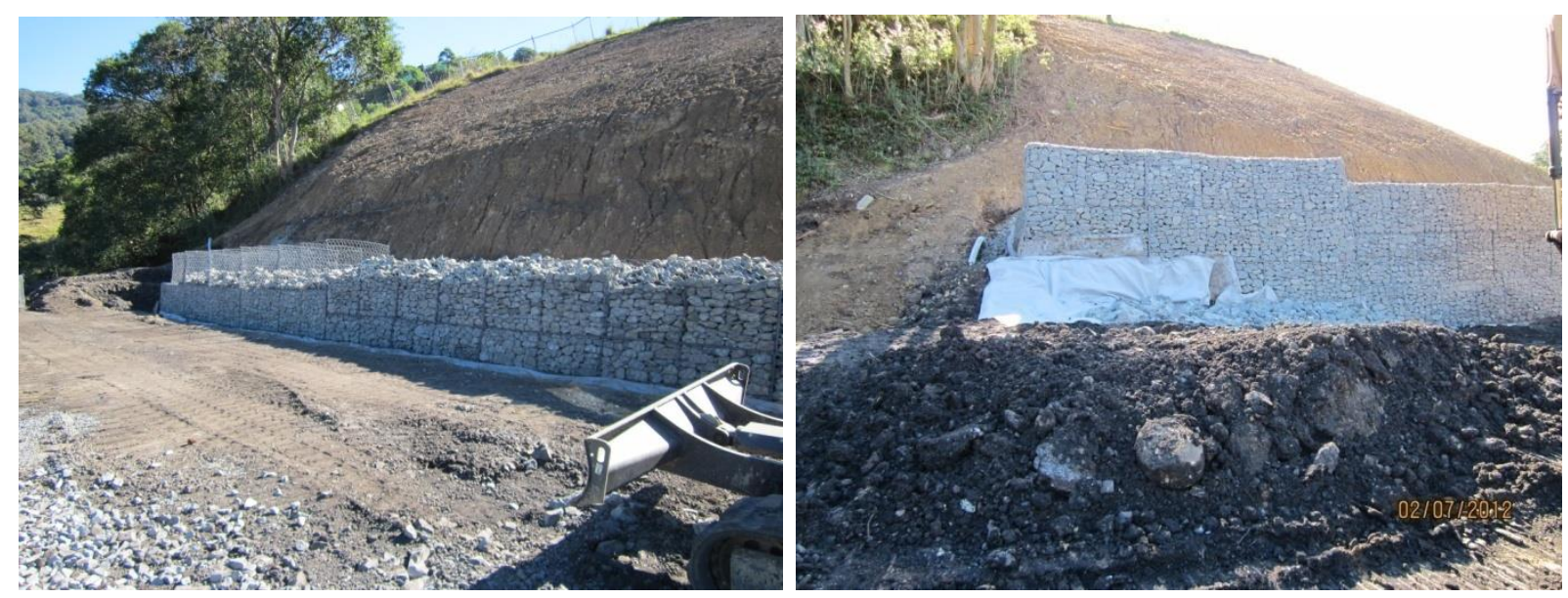

Figure 8 Stage 2 gabion wall structure under construction (as at July 2012) to stabilise incised railway embankment. This feature will allow Stage 2 Mt Kembla Mine Memorial Pathway to follow the original rail line, source: Cardno Pty Ltd (2011)

An example of soft creek bank stabilisation works used in Stage 1 is shown in Figure 9. This type of rehabilitation is preferred, however in areas of high velocity, harder rock armouring will be required.

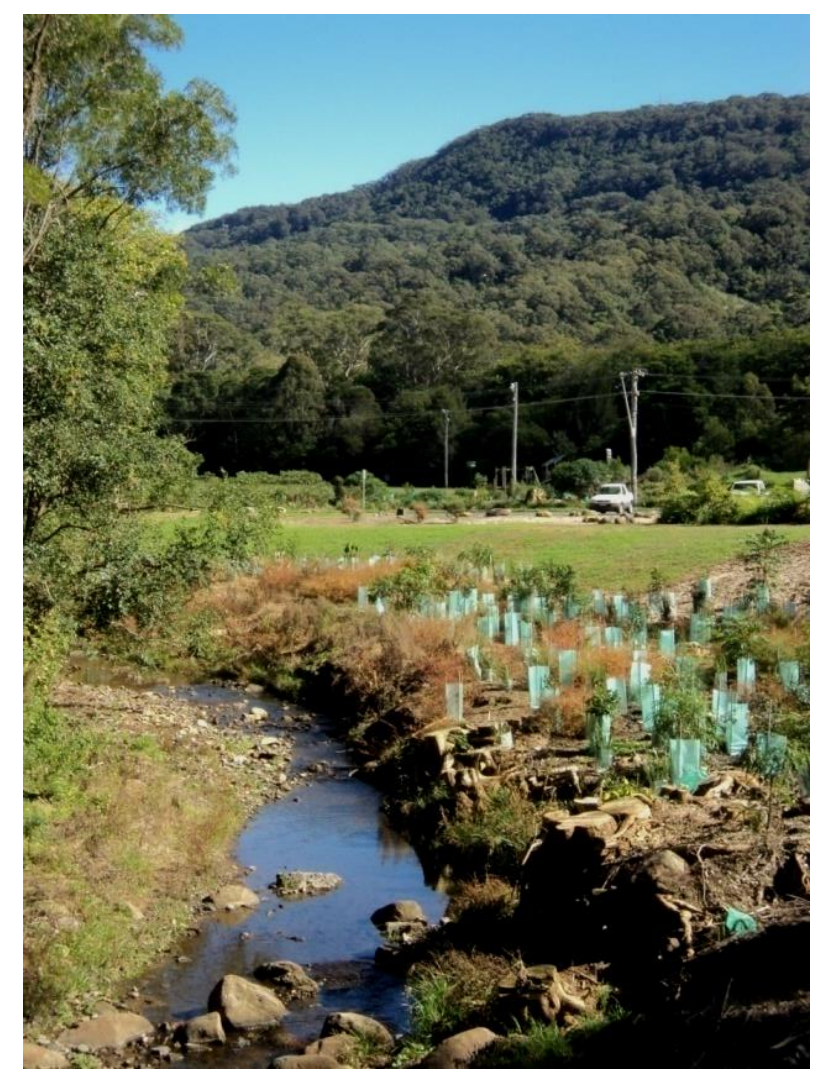

Figure 9 Example of small scale soft creek bank rehabilitation works in Stage 1 of the Mt Kembla Mine Memorial Pathway, source: Cardno Pty Ltd (2011) 
The development of the residential subdivision on a portion of suitable land satisfies a higher level outcome of 'Rehabilitation Hierarchy' than reinstating previous land use (e.g. grazing). This proposed final land use satisfies the sustainable rehabilitation aim of "developing an alternative outcome with a higher economic value than the previous land use" (Department of Environment and Resource Management, 2011). The residential subdivision is to be developed in an elevated portion of the site and will provide a continuity of the existing adjoining residential area. The block size, orientation and access have been designed with the overall future aesthetics of the site landscape and pathway accessibility in mind.

The size and character of new buildings within the new residential subdivision will need to comply with Wollongong Council Development Control Plans (DCP), which impose specific design restrictions on new residential developments. These include specific requirements for developments within the Illawarra Escarpment to ensure protection of aesthetic and environmental values within these areas.

The overall Stage 2 concept master plan design (see Figure 10) has considered the environmental and planning constraints which included riparian corridors, bushfire Asset Protection Zones (APZ), land zoning, land ownership boundaries, topography, soil character, drainage requirements and flooding potential (Cardno Pty Ltd, 2011).
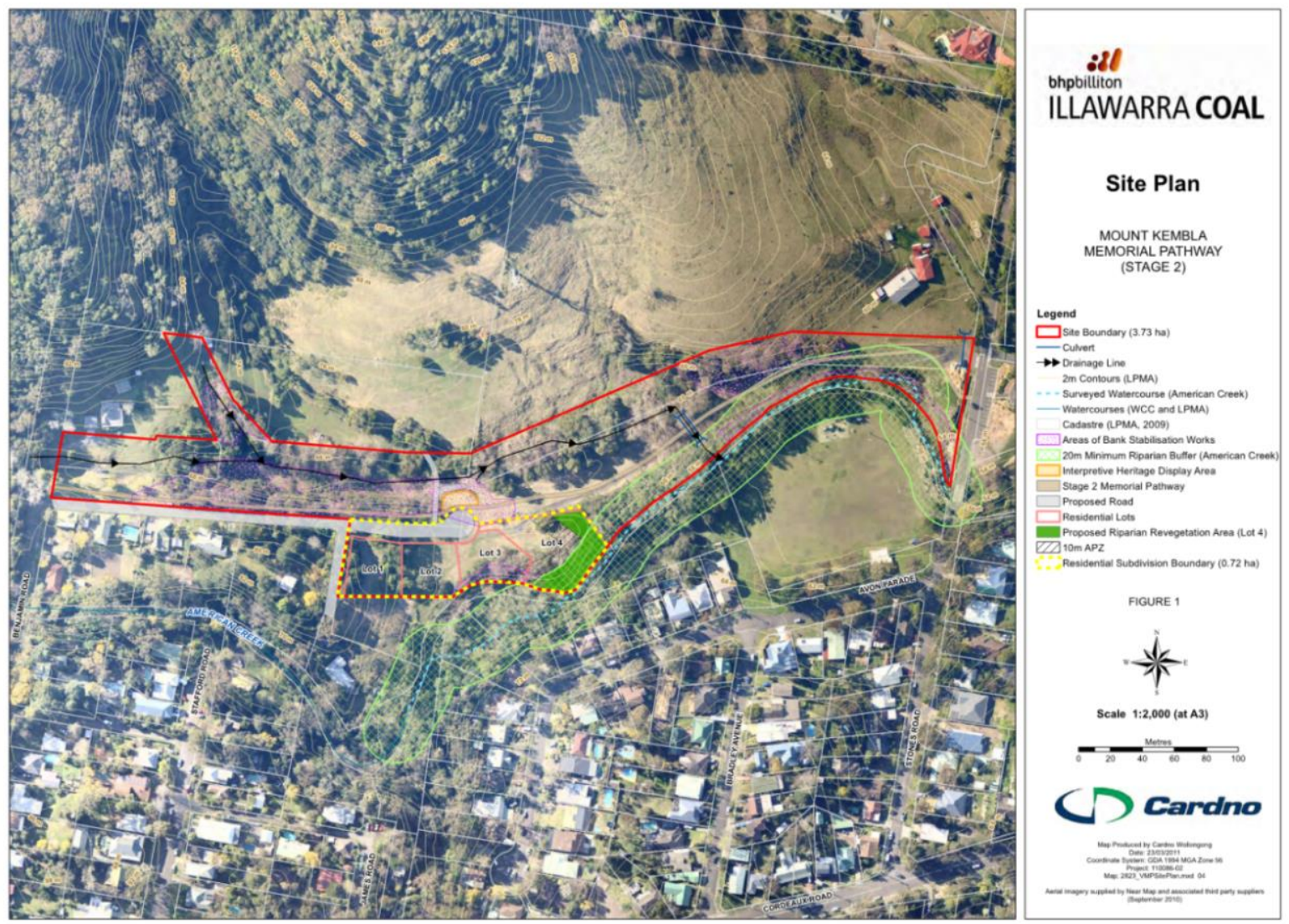

Figure 10 Initial concept plan showing the overall route of the proposed Stage 2 Mt Kembla Mine Memorial Pathway, the proposed subdivision and the rehabilitation zones, source: Cardno Pty Ltd (2011)

The approved landscape plans for Stage 2 (see Figure 11) have specified strategic plantings to screen the pathway area from the new residential subdivision. The use of aesthetically sensitive materials on boundary fences has also been specified to deal with a particular concern raised by the community. 



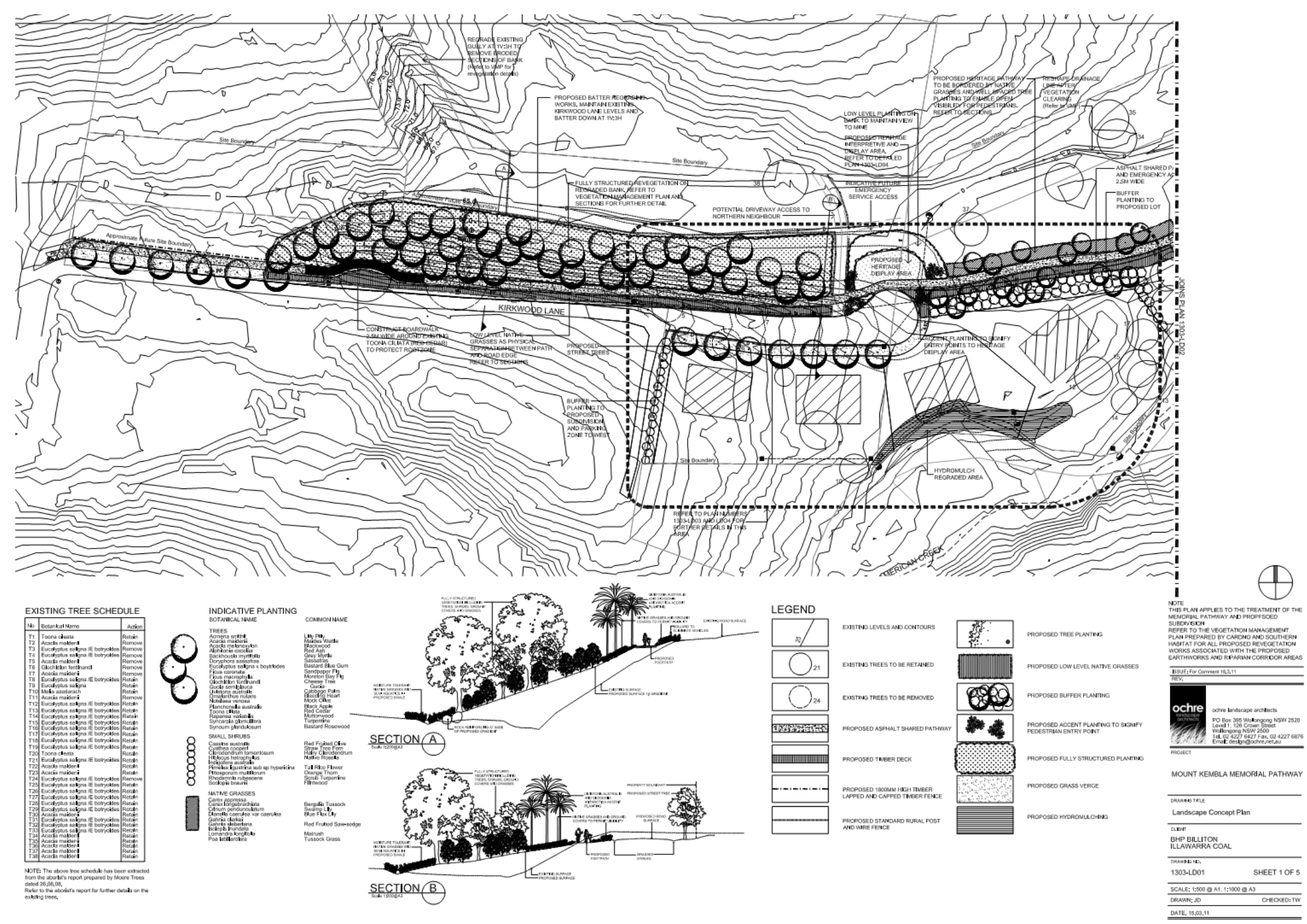

Figure 11 Stage 2 Mt Kembla Mine Memorial Pathway landscape architect concept design 



\subsection{Agency stakeholder engagement}

Once the preliminary site concept master plan was developed and agreed upon by both Illawarra Coal and community representatives, a site meeting was arranged with relevant agencies in attendance. The identification and engagement of key agency stakeholders was a crucial task to ensuring the establishment of the most appropriate approvals pathway. The following statutory authorities and government agencies were involved extensively throughout the development application process:

- Wollongong City Council.

- NSW Trade and Investment - Division of Resources \& Energy.

- NSW Office of Water.

- NSW Rural Fire Service.

A pre-lodgement meeting was held with Wollongong City Council to discuss the proposal with the respective Council departments prior to submission which included: planning, environment, subdivision, engineering and traffic representatives. This meeting proved to be very valuable as council were encouraged to support and be part of the project development team rather than being adversarial in their approach. This support helped to identify all of the detailed assessment pathways and requirements to satisfy the project approval requirements; especially in relation to ecological matters and the final residential subdivision design.

Liaison with the NSW Office of Water and Rural Fire Service was also crucial to ensure the final design met their specific requirements and expectations.

\section{$4 \quad$ Project approval requirements}

The planning assessment and approvals pathway for this particular project could have taken a couple of paths, which included assessment under Part 5 of the Environmental Planning and Assessment Act (EP\&A Act) 1979, whereby NSW Trade and Investment - Division of Resources and Energy (DRE) may have been the determining authority under their delegations of power under the Mining Act 1992.

The key factors that determined the most appropriate planning pathway for this project were the proposed public recreation area and residential subdivision. As Wollongong City Council had a vested future ownership interest in the portion of the site being donated to Council for public recreation and they would need to assess the residential development components in detail, it was agreed that the most suitable approval pathway was under Part 4 of the EP\&A Act, whereby Council would be the determining authority.

The proposed rehabilitation works, pathway, landscaping, roadways and residential subdivision had to be assessed for likely environmental impacts under Section 79C of the EP\&A Act through the preparation of a Statement of Environmental Effects (SEE). The requirements of the SEE were identified during a prelodgement meeting with Council.

All proposed engineering and landscape designs had to comply with the requirements of the Wollongong Local Environment Plan 2009, including relevant Development Control Plan 2009.

Some of the secondary approvals required included:

- NSW Office of Water (Controlled Activity Permit).

- NSW Trade and Investment - Division of Resources and Energy (Rehabilitation Plans and MOP Addendum).

- Wollongong City Council (Tree Removal, Subdivision Certificate, Construction Certificate).

A requirement for concurrence with NSW Rural Fire Service ensured that all proposed works would comply with the Planning for Bushfire Protection 2006. An additional concurrence requirement applied with NSW 
Trade and Investment - Division of Resources and Energy, to ensure all proposed rehabilitation plans would satisfy the requirements of the Mining Act 1992.

\section{$5 \quad$ Mine rehabilitation works}

The variety of elements across the site requiring rehabilitation means that a multitude of remedial activities are required. The overall mine rehabilitation works comprises of:

- Removal of extensive weedy vegetation.

- Re-shaping and stabilisation works along the degraded sections of American Creek and to rehabilitate and improve stability of old railway cuttings and embankments.

- Re-vegetation works and extensive replanting of native species along the riparian zone of American Creek and in other areas on the site.

- Installation of sediment and erosion controls and storm water management works.

- Ongoing monitoring and maintenance of rehabilitation works against predetermined performance indicators or completion criteria.

\subsection{Utilisation of coal wash as fill material}

The combined bulk earthworks strategy for the remediation of creek batters and batter stabilisation works requires the importation of approximately 10,500 cubic metres of suitable fill material to site. Stage 2 of this project is importing and beneficially reusing approximately 6,000 cubic metres of coal wash, a mine waste material, as engineered fill within the rehabilitation works. The controlled emplacement of all fill materials is in accordance with local Council guidelines and under geotechnical engineering supervision.

The management of construction vehicle and delivery truck impacts is an ongoing requirement during the construction phase. This requires consistent open communications with any residents experiencing issues due to the works, and especially those who make formal complaints. Any remedial actions proposed or stated were followed up expeditiously to ensure that they have been effective.

\subsection{Landscaping and revegetation works}

The design of landscaping and revegetation works across the site is guided by best practice restoration principles and the ecological assessment. This culminated in the preparation of a detailed Vegetation Management Plan (VMP) to detail a 'Restoration Plan of Action' and to outline the requirements of species selection, re-vegetation management zones, weed control requirements and ongoing monitoring and maintenance. The VMP was approved by the approval authorities and forms the guiding plan for site rehabilitation, particularly within the degraded riparian zones and steeper embankment areas.

A Council approved landscape plan developed by the landscape architect provides the plan for the more structured urban design elements across the proposed pathway and residential subdivision areas (see Figure 11).

Progressive revegetation of disturbed areas is immediately required following bulk earthworks and installation of engineering elements such as drainage features, retaining walls, services, paths and roadways. This process allows replanting works to establish and minimises the long term reliance on temporary erosion control measures (Cardno Pty Ltd and Southern Habitat Pty Ltd, 2011).

\subsection{Performance and closure criteria}

Performance indicators have been established for this project to ensure that the recommended program of works and strategies are achieved. Both quantitative and qualitative assessment of the floristic value of the site will be assessed at the recommended intervals during the ongoing maintenance and monitoring periods (Cardno Pty Ltd and Southern Habitat Pty Ltd, 2011). 
Agreement was obtained through liaison with Wollongong City Council and NSW Trade and Investment Division of Resources and Energy on acceptable and achievable rehabilitation performance and closure criteria, which were outlined within the VMP. These performance criteria will be monitored on an ongoing basis after rehabilitation construction works are complete to identify any areas not performing well and thus requiring additional maintenance, planting or additional treatments.

The valuable voluntary time and labour contributions that the community provided in the construction and maintenance activities of Stage 1 will be encouraged and supported during Stage 2 to ensure the long term viability and success of the project. This ongoing support will also provide assistance to the local Council once ownership has been transferred to them for the recreational areas of the site.

\section{$6 \quad$ Lessons learned}

- This project has demonstrated that effective and value added mine site rehabilitation planning, design and construction within an urban context is achievable, provided that both coordinated community and ecologically informed approaches are adopted.

- The essential first steps for progressing Stage 2 of the Mt Kembla Mine Memorial Pathway was to develop a shared vision amongst all stakeholders (community, company, agencies and consultants) of the future final land use opportunities and constraints at the site. This provided a sound foundation for a long term rehabilitation strategy for the site.

- Effective communication of the project's objectives, plans and progress to all stakeholders, including the community, is crucial to success. The regular meetings undertaken have encouraged community members to be actively involved in decisions, thus encouraging ownership of the project. This is likely to flow into on ground support with future site maintenance and monitoring of Stage 2, as was the experience with Stage 1.

- A consultative approach to planning should be an imperative for mine rehabilitation projects, as important values, opportunities and risks can be identified early in the project planning and design processes.

- Consultation approaches that are tokenistic or directive will not provide the value adding opportunity and risk reduction outcomes that can be achieved through a committed, inclusive and consistent two-way communications approach.

- Any cultural values associated with a rehabilitation site and surrounding environment can be quantified, understood, appreciated and considered within the design through thorough research and a concerted program of community engagement.

- Opportunities for beneficial reuse of mining waste materials, such as coal wash, within mine rehabilitation projects should be explored further during the planning phases of all rehabilitation projects.

- Responses to community concerns raised during construction phases need to be rapid and sincere and should always aim to provide a satisfactory resolution to any issues raised.

- Fostering a sense of ownership and stewardship with members of the community and community groups has proven to provide valuable assistance with ongoing restoration requirements and site maintenance.

\section{Conclusions}

Overall this project has required a unique blend of community focused consultation, environmental/ cultural assessment, town planning, landscape, and engineering design solutions to achieve the range of rehabilitation and urban design objectives for this particular mine site. 
Appropriate regulatory approval pathways and design options were determined through extensive stakeholder engagement, which along with a suite of supporting studies and subsequent management plans for the site have set the project up for ultimate success.

This project shows that effective rehabilitation planning for mine sites within an urban context can provide the opportunity to go beyond the expected ecological system restorative outcomes, as opportunities to improve cultural, recreational and educational amenities are also likely to be present.

The project will provide a number of economic benefits to the local area with temporary jobs during the construction phases of the rehabilitation works and future residential subdivision. The final finished pathway will provide attractive facilities that will be likely to increase numbers of tourists visiting the area which in turn will benefit local businesses within Mt Kembla village.

Engaging the community as a valued partner within the process of design and development of potentially sensitive projects fosters introduction of new and innovative ideas and ownership of decisions, which assist to ensure the project will be successful.

Honest and transparent two-way dialogue between the project development team and the community throughout all project phases has proven to be a valuable process for improving project outcomes, acceptance, approvals and delivery that should be encouraged within similar rehabilitation projects.

\section{Acknowledgement}

The following groups and individuals are acknowledged for their contribution to the planning and development of Stage 2 of the Mt Kembla Mine Memorial Pathway: The Community of Mt Kembla; Mt Kembla Pathway Group; Mr Chris Schultz (BHP Billiton Illawarra Coal); Wollongong City Council; NSW Trade \& Investment (Division of Resources \& Energy); NSW Office of Water; Mt Kembla Rural Fire Service; The staff at Cardno Pty Ltd; Ms Tracey Whiteman (Ochre Landscape Architects); Kevin Mills \& Associates (Flora \& Fauna Assessment); Mr Brian Rogers (Cultural Heritage Assessment); Douglas Partners (Geotechnical \& Contamination Assessment); EcoLogical Pty Ltd (Bushfire Assessment); Southern Habitat Pty Ltd (Bush Regeneration Contractor); Moore Trees Pty Ltd (Arborist Report); Craig Robson \& Associates Pty Ltd (Registered Surveyor).

\section{References}

Cardno Pty Ltd (2011) Statement of Environmental Effects, Proposed Mine Rehabilitation Works, Mt Kembla Mine Memorial Pathway (Stage 2) and 4 Lot Residential Subdivision, Kirkwood Lane, Mt Kembla, Prepared for BHP Billiton Illawarra Coal, March 2011.

Cardno Pty Ltd and Southern Habitat Pty Ltd (2011) Vegetation Management Plan, American Creek Rehabilitation Works, Prepared for BHP Billiton Illawarra Coal, March 2011.

Department of Environment and Resource Management (2011) Rehabilitation Requirements for Mining Projects, Queensland Department of Environment and Resource Management, March 2011, viewed 04/05/2012, http://www.ret.gov.au/resources/Documents/LPSDP/BPEMOverview.pdf.

Department of Sustainability and Environment (2004) Effective Community Engagement, Version 2, viewed 23/04/2012, http://www.cbt.infoxchange.net.au/cbrs/CommEngageWorkbook.pdf.

Douglas Partners (2011) Report on Geotechnical Investigation, Proposed Rehabilitation and Subdivision, Stones Road and Kirkwood Place, Mount Kembla, Prepared for Cardno Pty Ltd, March 2011.

Environment Australia (2002) Overview of Best Practice Environmental Management in Mining, viewed 23/04/2012, http://www.ret.gov.au/resources/Documents/LPSDP/BPEMOverview.pdf.

Rogers, B. (2005) Heritage and Archaeological Assessment of Certain Colliery Railway Land at Mt Kembla, Proposed Rezoning Application, BHP Billiton Land, Kirkwood Place, Mount Kembla, City of Wollongong, Prepared for BHP Billiton, March 2005.

Wollongong City Council (2009) Wollongong Local Environment Plan 2009, Under the Environmental Planning and Assessment Act 1979 (2010 No 76). 